\title{
THE EFFECTS OF FEEDING METHODS AND REGIMES ON PERFORMANCE OF HYBRID TILAPIA, OREOCHROMIS NILOTICUS X O. AUREUS, REARED IN CAGES.
}

\section{Mohamed A. Essa}

National Institute of Oceanography and Fisheries, Kayet Bey, Alexandria , Egypt.

(Received : November 9, 1999)

Key words: Rearinging, Feeding methods, Regimes, Tilapia hybrids, Cages.

\section{ABSTRACT}

In order to study the optimum feeding methods and frequency in hybrid tilapia, Oreochromis niloticus (female) x O. aureus (male), 2400 fingerlings were divided into four groups in duplicated floating net-cages $\left(2 \mathrm{~m}^{3}\right.$ each). The same feed ration ( $27.9 \%$ crude protein) as percentage of biomass was given to all experimental groups but with different feeding methods (automatic on demand feeding or manual) and frequencies $(2,4$ and 6 times daily). The results indicated that: 1) fish fed from demand feeders ( 8 hours daily) gained more weight, showed better feed utilization, and higher survival rate and production than fish fed manually, and 2) the higher feeding frequencies between 4 and 6 times daily resulted in superior weight and length gains, conditions factor, feed utilization, survival and production as well as a favorable influence on lipid and protein assimilation, compared to fish fed two times daily.

\section{INTRODUCTION}

In intensive fish culture with species of high fecundity, which can spawn freely in ponds, such as tilapias, one promising method of 
eliminating unwanted reproduction and so carrying out the maintenance of the populational density, is the culture of all-male tilapia hybrids (Hickling, 1963; Lovshin, 1982; Tave, 1988; Salama and Abd ElRaheem, 1995). In tilapia, males grow at faster rate than females (Bardach et al., 1972; Guerrero, 1982). A considerable number of crosses between tilapia species resulted in high proportions (over $85 \%$ ) of male hybrids (Lovshin, 1982; Mires, 1982; Majumdar and McAndrew, 1983 ; Essa and Haroun, 1998).

Competition for food is an important limiting factor for growth of young fish. Competition and aggressive behaviour increase under situations of food shortage (Symnons, 1971; Essa, 1996). Earlier experiments have shown that growth rate and behaviour in salmonids (Symons, 1971; Refstie and Kittelsen, 1976), tilapia and mullet (Essa et al., 1989) are influenced by food availability and/or density. Many studies with higher vertebrates have shown also that different feeding regimes may influence a number of physiological variables, including weight gain and fattening (Nelson et al., 1975; Philippens et al., 1977). However, many problems related to feeding conditions remain to be solved.

The application of knowledge on feedstuffs and their optimal formulation is of no value if feeding methods are not used to the best advantage. Therefore, the present study combines an investigation into the effect of feeding methods (automatic on demand feeding or manual feeding) and the frequency of feeding (2,4 and 6 times daily) on growth and production performance of the tilapia hybrid, female Oreochromis niloticus $\mathrm{x}$ male $O$. aureus, under intensive management operations in cages. 
The effects of feeding methods and regimes on performance of --hybrid tilapia species reared in cages

\section{MATERIAL AND METHODS}

Fish and rearing conditions:

The experiment was conducted between 2 April and 6 August, 1999 (95 days) at Alexandria Governorate Fish Farm, Alexandria, Egypt.

The all male tilapia hybrids used in this study were produced in brood ponds during the summer of 1998 , by crossing female Nile tilapia, Oreochromis niloticus, with male blue tilapia, $O$. aureus. The production of males in two pair crosses was $91 \%$ and $93 \%$.

Six hundred tilapia hybrid fingerlings with mean initial weight of $15.50 \pm 1.02 \mathrm{~g}$ were fed from demand feeders suspended above two cages $\left(1.0 \times 2.0 \times 1.0 \mathrm{~m}\right.$ water depth, $2 \mathrm{~m}^{3}$ water volume each), cages were stocked at rate of $150 \mathrm{fish} / \mathrm{m}^{3}$. The demand feeder only releases feed when the bait is actually pulled (Fig. 1). Feed was available only between 8.0 and 16.00 hours (day). No food is dispensed when it is accidentally touched.

A total of 1800 tilapia hybrid fingerlings averaging $14.90 \pm 0.44 \mathrm{~g}$ in body weight were divided into three groups in six nylon net-cages $\left(2 \mathrm{~m}^{3}\right.$ each), fish were stocked at a rate of $150 \mathrm{fish} / \mathrm{m}^{3}$ into the experimental cages. The three experimental groups with different feeding frequencies were fed manually and designed as follows: two times daily ( $2 \times$ group, 9.000 a.m., 15.00 p.m.), four times daily ( $4 x$ groups, 8.0, 11.00 a.m., $13.30,16.00$ a.m.) and six times daily (6x group, 8.00, 9.30, 11.00 a.m., $12.30,14.00,16.00$ a.m.). The same feed ration (Table 1) was fed as percentage of biomass to all experimental groups at a rate of $4 \%$ of body weight per day in moist pelleted form containing $27.9 \%$ crude protein. Each group of fish was weighed once every two weeks and the amount of diet fed was adjusted accordingly. 
Water quality criteria in cages area were monitored at least once weekly.

\section{Biological measurements:}

Total length to the nearest $\mathrm{mm}$ and body weight to the nearest 0.1 $\mathrm{g}$ of 30 individuals randomly selected fish from each cage were measured bi-weekly. The condition factor $(k)$, daily growth rate, survival percentage and feed conversion ratio were also determined according to Kayano et al. (1993). The total biomass for each group was also employed during all experimental intervals and at the end of the experiment.

\section{Biochemical measurements:}

Chemical analysis of feed and fish were carried out according to the methods described by Nauman and Bassler (1976).

Statistical analysis:

The differences among the experimental groups for different parameters were tested for statistical significance using analysis of variance and Duncan's Multiple Range Test according to Snedecor and Cochran (1967).

\section{RESULTS AND DISCUSSION}

1. Water quality in cages area:

Studying the water quality is of prime importance in regulating and following the suitability of the water for holding and rearing fish.

During the present study, it has been found that water temperature ranged between 21.0 and $30.9^{\circ} \mathrm{C}$. This range is suitable for fish growth and survival. Nagel (1979) reported that water temperature over $18{ }^{\circ} \mathrm{C}$ was best for fish survival and growth, and noticed the death of many species below $12^{\circ} \mathrm{C}$.

Turbidity in the cages area is mainly caused by suspended soil particles and plankton that did not exceed $3.0 \mathrm{mg} / 1$ (Table 2). According 
The effects of feeding methods and regimes on performance of hybrid tilapia species reared in cages

to Hassan and Essa (1995), behavioral reactions of fish occurred when turbidities exceeded $20,000 \mathrm{mg} / 1$. Chlorosity in the water ranged between 1.1-1.6 $\mathrm{g} / \mathrm{l}$. This level classifies such water as freshwater.

The oxygen level in the cages area was desirable and measured more than $5.4 \mathrm{mg} / \mathrm{l}$. The lowest tolerance limits of dissolved oxygen for tilapia have been reported to range from 0.1 to $3.0 \mathrm{mg} / 1$ (Ross and Ross, 1983).

The results summarized in Table (2) show also that, the $\mathrm{pH}$ values were suitable for fish growth and ranged between 7.0-8.9 (Alabaster and Lioyd, 1980).

The total alkalinity of the cages area fluctuated between 131-147 $\mathrm{mg} /$ l. According to Maar et al., (1974), water with total alkalinity of more than $50 \mathrm{mg} / \mathrm{l}$ contain suitable amount of carbon dioxide to permit plankton production for fish culture.

Concentrations of inorganic nitrogen, $\mathrm{NH} 3$, in water were very low and ranged from $0.06-0.12 \mathrm{mg} / \mathrm{l}$ (Table 2) while the concentration of orthophosphate ions were moderate.

The BOD (Biological oxygen demand) is a measure of the amount of oxygen required by micro-organisms to decompose the organic matter in water. The BOD in the cages area was found to be very low, between 1.70-1.92 mg/l (Table 2). On the other hand, the chemical oxygen demand (COD) or the total amount of oxygen required to completely oxidize all of organic matter in water, was higher than that of BOD. This may be due to the relatively high concentrations of organic matter in cages area.

Table (2) revealed also that the biological measurement of Chlorophyll-a indicates that the water has a moderate amount of phytoplankton. 
Therefore, the results of water quality demonstrate the suitability of the environment for fish culture in the area of the study.

\section{Growth performance parameters as affected with feeding} methods and regimes:

The feeding methods and frequency of daily feeding are of major importance in intensive warmwater fish culture because the fish, in contrast to pond culture, are entirely dependent on the nutrition provided for them. The growth in weight and length, condition factor, total production $\left(\mathrm{kg} / \mathrm{m}^{3}\right)$ as well as survival percentage of hybrid tilapia, $O$. niloticus $\mathrm{x} O$. aureus, reared in $2 \mathrm{~m}^{3}$ floating net-cages at different feeding methods (manual or automatic on demand feeding) and frequencies $(2,4$ and 6 times daily) are shown in Table 3 . The results show clearly that fish fed from demand feeders (Fig.1) 8 hours daily $(8.00-16.0 \mathrm{~h}$ ) gained significantly $(p<0.05)$ more in weight and length as well as total production than fish fed manually. It was noted that tilapia hybrids were adapted very quickly to this new technology of feeding. After few days, the fishes, learned to react to the bait and gathered around the feeders. The average condition factor and survival percentage of fish fed from demand feeders followed the same general pattern as the weight and length gains. These results are in agreement with previous findings of ElShahat (1998) for red tilapia culture in net-enclosure and fed from demand feeders or for carp yearlings fed from automatic feeders (Swierzowski, 1989). This may be because of the fact that the demand feeder only releases feed when the bait is actually pulled. Also, a demand feeder gives the fish a chance to obtain at all times the food it requires. According to Meske (1985) that the fish is the best judge of its environment and requirements than any measuring devices. 
The effects of feeding methods and regimes on performance of hybrid tilapia species reared in cages

Table (3) illustrates also the results of the effects of feeding frequency on growth and production of hybrid tilapia. It is also interesting to note from the present experiment that, feeding frequency was positively correlated to gain in weight and length, condition factor, total fish production and survival percentage. In addition, the high feeding frequencies reduced size variation in the fish. However, there were no significant differences in growth and production performance among tilapia hybrid groups fed manually four or six times daily. According to Omar and Günther (1987) and El-Ebiary (1998), increasing feeding frequency improved body weight gain in mirror carp. Channel catfish fed a half ration by two times daily showed growth and feed conversion efficiency similar to those of fish which were fed a single early meal and abdominal fat responded to feeding time (Noeske et al., 1985). Also, Kayano et al. (1993) suggested that, a feeding frequency between four and six times daily is optimum for achieving optimum growth rates in young red-spotted grouper, Epinephelus akaara.

Concerning biochemical measurements, the body composition of tilapia hybrid fed manually at different frequencies or from demand feeders are shown in Table 4. Results revealed that fish fed from demand feeders had the highest protein content. while the lipid and ash content were highly influenced by the feeding frequency. Higher feeding frequencies ( 4 and 6 times daily) and demand feeders groups tended to have higher body lipid and ash contents as well as lower moisture content compared to fish fed two times a day. The enzymes involved in the conversion of glucose and fat might be affected by the meal frequency which in turn could affect the ability to utilize carbohydrate and fat. Tung and Shiau (1991) found that phosphofructokinase (PEK) and 6 phosphogluconate dehdrogenase (6 PGD) activities were higher in fish fed six times a day than in fish fed two times. day. Cohn and Joseph 
(1960) noted that meal feeding altered body composition (increased fat stored in rats) by enhancing lipogenic activity.

On the other hand, the feed conversion ratio (FCR) of tilapia hybrid fed manually at the different frequencies or from demand feeders, followed the same general pattern as the weight gain (Fig. 2). The fish fed from demand feeders used less feed (1.79 units) to produce one unit of gain in body weight. Also, the fish fed manually 4 and 6 times daily used feed more efficient than those fed two times daily. According to kayano (1993), the low feeding frequencies might cause metabolic changes depressing protein assimilation and accumulation of phospholipids in the muscle.

In conclusion, a demand feeder gives the fish a chance to obtain at all times the food it requires especially when fish densities were extremely high (intensive culture) and achieved the best and fastest feed utilization and growth. In case of manual feeding, the higher feeding frequency between four and six times daily resulted in superior body weight and length gains, condition factor, survival percentage, total production, feed conversion ratio and exerted a favorable influence on lipid and protein assimilation, compared to fish fed two times daily.

\section{REFERENCES}

Alabster, J.S. and Lioyd, R.L. (1980): Water quality criteria for freshwater fish. Bullerworth. London and Bostn, $297 \mathrm{pp}$.

Bardach, J.E., Ryther, J.H. and McLarney, W.D. (1972): Aquaculture. The farming and husbandry of freshwater and marine organisms. Wiley, New York, N.Y., 868 pp.

Cohn, C. and Joseph, D. (1960): Role of rate of ingestion of diet on regulation of intermediary metabolism (meal eating vs nibbling). Metablosim, 9:492-500. 
The effects of feeding methods and regimes on performance of $\therefore$ hybrid tilapia species reared in cages

El-Ebiary, E.H. (1998): Breeding of tilapia and mullet together in floating cages under different stocking densities and feeding frequencies. Egypt. J. Aquat. Biol and Fish., 2(1):141-162.

El-Shahat, M.I. (1998): Studies on the culture of red tilapia in netenclosures. M.Sc. Thesis, Fac. Science, Tanta Univ., Tanta, Egypt, 172p.

Essa, M.A. (1996): The effect of fish density and feeding frequency on both $O$. niloticus and Mugil cephalus fish reared as mixed culture on floating cagres. Bull. Nat. Inst. Oceanogr. and Fish. ARE, Vol. 22: 181-197.

Essa, M.A. and Haroun, M.R. (1998): Cross-breeding experiments on some important fishes of family Cichlidae (Genus Oreochromis) and evaluation of their hybrids. Egypt. J. Aquat. Biol. And Fish., 2(3): 43-61.

Essa, M.A., El-Sherif, Z.M., Aboul-Ezz, S.M. and Abdel Moati, A.R. (1989): Effect of water quality, food availability and crowding on rearing conditions and growth of some economical fish species grown under polyculture systems. Bull. Nat. Inst. Oceanogr. and Fish., ARE 15(1): 125-134.

Guerrero, R.D. (1982): Control of tilapia reproduction, P. 309-316. In: R.S.V. Pullin and R.H. Lowe-McConnell (eds.). The biology and culture of tilapias. ICLARM Conf. Proc. 7, 432 p. ICLARM, Manila, Philippines.

Hassan, N.A. and Essa, M. A. (1995): Studies on the water quality criteria in the Nile from Naga Hammadi to Assiut and possibilities for establishing modern fish culture. Delta J. Sci. 19(2): 295-317.

Hickling, C.F. (1963): The cultivation of tilapia. Sci. Am., 203 (5): 143152.

Kayano, Y.; Shanjing, Y.; Syozo, Y. and Heisuke, N. (1993): Effect of feeding frequency on the growth and body constituents of young 
red-spotted grouper, Epinephelus akaara. Aquacultre, 110: 271278.

Lovshin, L.L. (1982): Tilapia hybridization, p. 279-308. In: R.S.V. Pullin and R.H. Lowe-McConnell (eds). The biology and culture of tilapias. ICLARM Conf. Proc. 7, 432 p. ICLARM, Manila, Philippines.

Maar, A., Mairs, D.F. and Malca, R.P. (1974): A total alkalinity atlas for Maine Lake water. Limnol. Oceanogr., 11:68-72.

Majumdar, K.C. and McAndrew, B.J. (1983): Sex ratios from interspecific crosses within the tilapias, P. 261-269. In: Intern. Symp. Tilapia in Aquaculture. Tel Aviv Univ., Tel Aviv, Israel.

Meske, Ch. (1985): Fish aquaculture, technology and experiments. Pergamon Press Ltd. Headington Hill Hall, Oxford, England, 237 p.

Mires, D. (1982): A study of the problems of the mass production of hybrid tilapia fry, P. 317-329. In: R.S.V. Pullin and R.H. LoweMcConnell (eds.). The biology and culture of tilapias. ICLARM Conf. Proc. 7, 432 p. ICLARM, Manila, Philippines.

Nagel, L. (1979): Aquaculture in the third world. J. Anim. Res. and Develop., 9:77.

Nauman, K. and Bassler, R. (1976): Methodenbuch Band III. Die chemische untersuchung von Futtormitteln. Verlag. J. NeumanNeudamm.

Nelson, W., Scheving, L. and Halberg, F. (1975): Circadian rhythms in mice fed a single daily meal at different stages of lighting regimen. J. Nutrition, 115: 1228-1232.

Noeske, T.A., Spieler, R.E., Parker, N.C. and Suttle, M.A. (1985): Feeding time differentially affects fattening and growth of channel catfish. J. Nutr., 115: 1228-1232.

NRC (National Research Council) (1993): Nutrient requirements of warm-water fishes and shell-fishes. National Academy of sciences, Washington, DC. Pp. 102. 
The effects of feeding methods and regimes on performance of -hybrid tilapia species reared in cages

Omar, E.A. and Günther, K.D. (1987): Studies on feeding of mirror carp (Cyprinus carpio) in intensive culture. J. Anim. Physiol. Anim. Nutr. 57: 172-180.

Philippens, K.M.H., Von Mayersbach, H., and Scheving, L. (1977): Effects of the scheduling of meal-feeding at different phases of the circadian system in rates. J. Nutrition, 107: 176-193.

Refstie, T. and Kittelsen, A. (1976): Effect of density on growth and survival of artificially reared Atlantic salmon. Aquaculture, 8: 319-326.

Ross, B. and Ross, L.G. (1983): The oxygen requirement of Oreochromis niloticus under adverse conditions. Proc. Intern. Symp. Tilapia In Aquaculture, Tel Aviv. Univ., Israel, pp. 134-143.

Salama, M.E. and Abd El-Raheem, M.M. (1995): Monosex tilapia "Oreochromis niloticus" production under commercial fish farm conditions. J. Egypt. German Soc. Zool., Vol. I8(B): 46-68.

Snedecor, G.W. and Cochran, W.G. (1967): Statistical methods. $6^{\text {th }}$ Ed. Iowa state Univ. Press, Ames., lowa, USA.

Swierzowski, A. (1989): Methods and effects of automatic feeding of carp yearlings with pellets. J. Aquatic products, Istanbule Univ., Istanbul, Turkey, 3(1-2):97-106.

Symons, P.E.K. (1971): Behavioural adjustment of population density to available food by juvenile Atlantic salmon. J. Anim. Ecol., 40: 569-587.

Tave, D. (1988): Genetic and breeding of tilapia: a review, P. 285-293 in: R.S.V. Pullin, T. Bhukaswan, K. Tonguthni and J. L. Maclean (eds.). The second Intern. Symp. Tilapia in Aquaculture. ICLARM Conf. Proc., 15, 623 p. ICLARM, Manila, Philippines.

Tung, P.H. and Shiau., S.Y. (1991): Effects of meal frequency on growth performance of hybrid tilapia, $O$. niloticus $\times O$. aureus, fed different carbohydrate diets. Aquaculture, 92: 343-350. 
Table (1): Formulation and proximate composition of the artificial diet used for feeding tilapia hybrid fingerlings in net-cages.

\begin{tabular}{|l|c|}
\hline Ingredients & \% Inclusion \\
\hline Cotton seed cake & 30.00 \\
Wheat bran & 20.00 \\
Rice bran & 15.00 \\
Sesame cake & 7.75 \\
Beer wastes & 15.00 \\
Fish meal & 5.00 \\
Blood meal & 5.00 \\
Bone meal & 2.00 \\
Vitamin mixture & 0.25 \\
\hline Total & 100 \\
\hline Chemical analysis: & \\
Dry matter & 39.10 \\
Crude protein & 27.90 \\
Ether extract & 6.30 \\
Ash & 10.60 \\
N-free extract & 37.10 \\
Fibers & 11.20 \\
Gross energy (K cal/ 100g) & 369.31 \\
\hline
\end{tabular}

$>$ Gross energy was calculated based on $5.64,9.44$ and $4.11 \mathrm{Kcal} / \mathrm{g}$ for protein, lipid and carbohydrate, respectively (NRC, 1993). 
The effects of feeding methods and regimes on performance of - hybrid tilapia species reared in cages

Table (2): Water quality criteria in the experimental cages area.

\begin{tabular}{|l|l|}
\hline Item & Range \\
\hline Water temperature $\left({ }^{\circ} \mathrm{C}\right)$ & $21.0-30.9$ \\
Turbidity $(\mathrm{mg} / \mathrm{l})$ & $2.40-3.00$ \\
Chlorosity $(\mathrm{g} / \mathrm{l})$ & $1.10-1.60$ \\
Dissolved oxygen $(\mathrm{mg} / \mathrm{l})$ & $5.40-8.50$ \\
$\mathrm{PH}$ & $7.00-8.90$ \\
Total alkalinity $(\mathrm{mg} / \mathrm{l})$ & $131.00-147.00$ \\
Ammonia- $\mathrm{NH}_{3}(\mathrm{mg} / \mathrm{l})$ & $0.06-0.12$ \\
Orthophosphate- $\mathrm{PO}_{4}(\mathrm{mg} / \mathrm{l})$ & $0.012-0.104$ \\
Biological oxygen demand $(\mathrm{BOD}-\mathrm{mg} / \mathrm{l})$ & $1.70-1.92$ \\
Chemical oxygen demand $(\mathrm{COD}-\mathrm{mg} / \mathrm{l})$ & $5.00-7.13$ \\
Chlorophyll-a $\left(\mathrm{mg} / \mathrm{m}^{3}\right)$ & $0.3248-0.4464$ \\
\hline
\end{tabular}




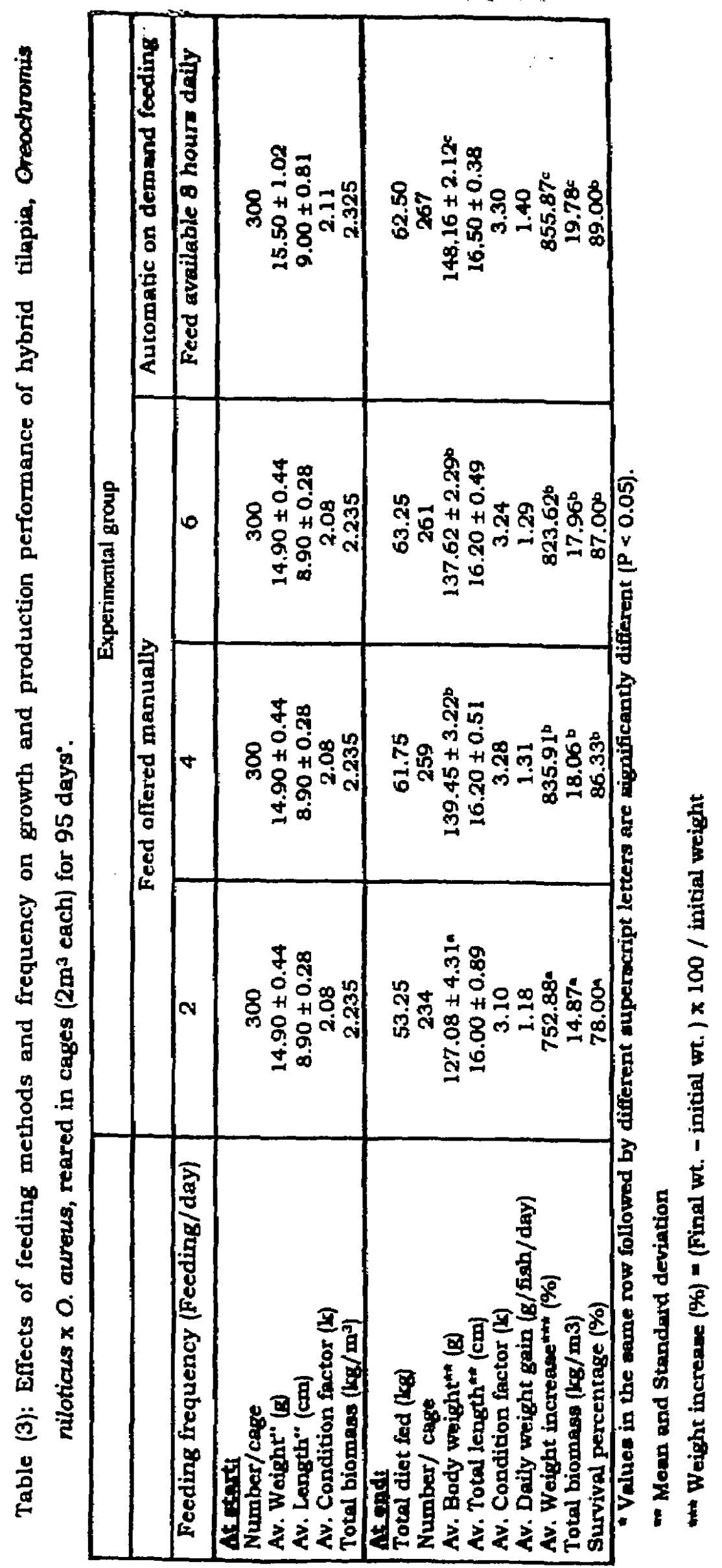


The effects of feeding methods and regimes on performance of -uhybrid tilapia species reared in cages

Table (4): Effects of feeding methods and frequency on body composition of hybrid tilapia reared in net-cages for 95 days.

\begin{tabular}{|c|c|c|c|c|}
\hline \multicolumn{5}{|c|}{ Experimental group } \\
\hline \multicolumn{4}{|c|}{ Feed offered manually } & Automatic on \\
\hline $\begin{array}{l}\text { Feeding frequency } \\
\text { (feeding/day) }\end{array}$ & 2 & 4 & 6 & $\begin{array}{c}\text { Feed available } 8 \\
\text { hours daily }\end{array}$ \\
\hline Crude protein & $15.23 \pm 0.79$ & $15.49 \pm 0.80$ & $16.03 \pm 0.62$ & $16.07 \pm 0.41$ \\
\hline Crud lipid & $3.86 \pm 0.77$ & $4.78 \pm 0.93$ & $5.92 \pm 1.05$ & $4.98 \pm 1.03$ \\
\hline Ash & $3.92 \pm 0.56$ & $4.09 \pm 0.33$ & $4.31 \pm 0.29$ & $4.22 \pm 0.27$ \\
\hline Moisture & $77.12 \pm 1.09$ & $75.87 \pm 2.13$ & $74.05 \pm 2.75$ & $74.99 \pm 2.67$ \\
\hline
\end{tabular}




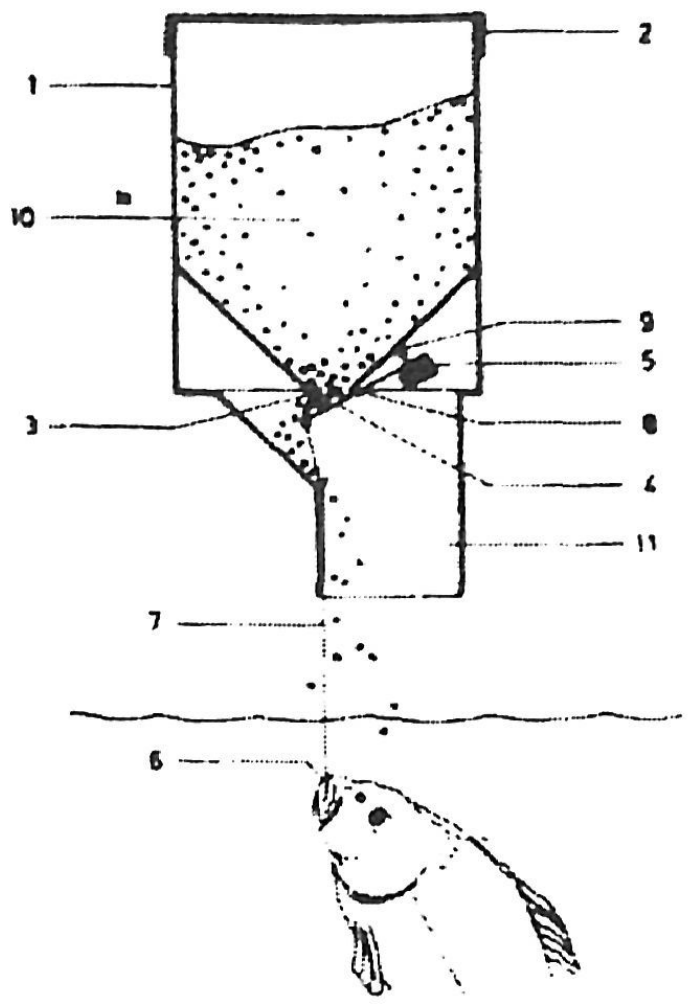

Fig. (1). Demand of self-feeder.

(1) with lid (2) has opening at the bottom (3) which is kepl closed by flap (4) and counterweight (5). To feed, the fish has to pull the rubber bait (6) which, through a cord (7). opens flap (4) until the hinge (8) and weight (5) hit the stop (9). As long as the fish pulls, feed (10) drops through the opening (3) into the water. Chute (11) protects the mechanism against splashing. Counterweight (5) Shuts opening (3) immediately the fish stops pulling.

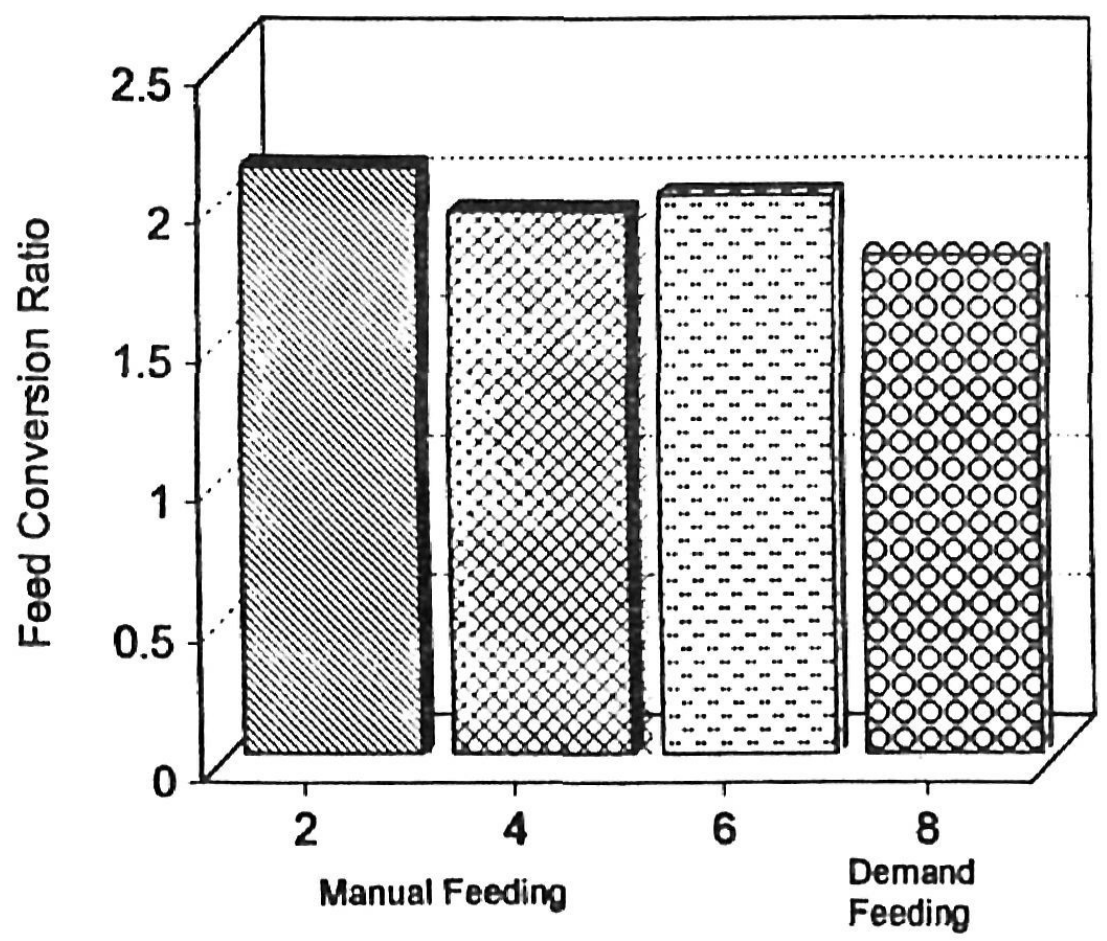

Fig. (2): Effects of feeding methods and frequency on feed conversion ratio of hybrid tilapia reared in cages for 95 days. 